\title{
PSIKOEDUKASI TENTANG RISIKO PERKAWINAN USIA MUDA UNTUK MENURUNKAN INTENSI PERNIKAHAN DINI PADA REMAJA
}

\author{
Zainul Anwar ${ }^{1 *(D)}$, Maulida Rahmah ${ }^{2}$ \\ ${ }^{1,2}$ Fakultas Psikologi, Universitas Muhammadiyah Malang, Malang, Indonesia
}

\begin{abstract}
There were several reason people married at an early age, one of the reason was their strong intention. Married at an early age intention is the tendency to get married before the age of 20. The increasing tendency to get married at the early age can be solved, psych education is one way to that can be done. The aim of the research is to know the effect of psych education given to decrease the intention of getting married at the early age. 55 teenagers participated as respondent. Purposive sampling was used as sampling technique. Quasi-experimental with pre-test and post-test one design was used as research method. There were significant differences on score between group with psych education and group without psych education $t(-39,305 ; p=0.000<0.05)$. Therefore, psych education is an effective method to decrease the intention of getting married at an early age.
\end{abstract}

Keywords: Psych education, Marriage at an early age intention, Teenager.

\begin{abstract}
ABSTRAK
Berbagai alasan bagi seseorang melakukan pernikahan usia dini, salah satunya adalah kondisi seseorang yang memiliki keinginan kuat untuk menikah pada usia muda. Intensi pernikahan dini merupakan kecenderungan menikah diusia remaja atau di bawah umur 20 tahun. Meningkatnya intensi pernikahan dini dapat diatasi, salah satunya dengan memberikan psikoedukasi. Tujuan penelitian ini adalah untuk mengetahui adanya pengaruh pemberian psikoedukasi perkawinan usia muda dalam menurunkan intensi pernikahan dini pada remaja. Subjek penelitian berjumlah 55 remaja yang diambil secara purposive. Penelitian ini adalah penelitian eksperimen quasi. Jenis penelitian ini menggunakan metode pre experimental design dengan jenis pre-test and post-test one group design. Hasil penelitian menunjukkan terdapat perbedaan skor yang signifikan terhadap perlakuan tanpa psikoedukasi dan dengan diberikan perlakuan psikoedukasi t ($39,305 ; \mathrm{p}=0.000<0.05)$. Dengan demikian, dapat disimpulkan bahwa psikoedukasi dapat digunakan untuk menurunkan intensi pernikahan dini.
\end{abstract}

Kata kunci: Psikoedukasi, Intensi pernikahan dini, Remaja 


\section{PENDAHULUAN}

Pernikahan dini merupakan pernikahan pada remaja dibawah usia 20 tahun yang seharusnya belum siap untuk melaksanakan pernikahan. Masa remaja juga merupakan masa yang rentan resiko kehamilan karena pernikahan dini (usia muda). Diantaranya adalah keguguran, persalinan prematur, berat badan lahir rendah (BBLR), kelainan bawaan, mudah terjadi infeksi, anemia pada kehamilan, keracunan kehamilan dan kematian. Dampak dari pernikahan dini yang dilakukan remaja yakni akan mengalami tekanan psikis yang berakibat pada pernikahannya maupun kepada anaknya jika kelak ia memiliki anak. Lebih jauh lagi, pernikahan dini akan mempengaruhi kualitas keluarga dan berdampak langsung pada rendahnya kesejahteraan keluarga. Dikalangan remaja pernikahan dini dianggap sebagai jalan keluar untuk menghindari dosa yaitu seks bebas. Ada juga yang melakukannya karena terpaksa dan hamil diluar nikah. Fenomena tersebut sering kita dengar di masyarakat, namun bukan kah pernikahan itu tidak hanya sekedar ijab qabul dan menghalalkan yang haram. Melainkan kesiapan moril dan materil untuk mengarungi dan berbagi apapun kepada pasangan tercinta (Kusmiran, 2011).

Menurut United Nations Development Economic and Social Affairs (UNDESA, 2010),
Indonesia merupakan negara ke-37 dengan jumlah pernikahan dini terbanyak di dunia di tahun 2007. Untuk level ASEAN, tingkat pernikahan dini di Indonesia berada diurutan kedua terbanyak setelah Kamboja.

Riskesdas (2010) Perempuan muda di Indonesia dengan usia 10-14 tahun menikah sebanyak 0,2 persen atau lebih dari 22.000 wanita muda berusia 10-14 tahun di Indonesia sudah menikah. Jumlah dari perempuan muda berusia 15-19 tahun yang menikah lebih besar jika dibandingkan dengan laki-laki muda berusia 15-19 tahun (11,7\% perempuan dan 1,6\% laki-laki usia 15-19 tahun). Di antara kelompok umur perempuan 20-24 tahun lebih dari 56,2\% sudah menikah. Selain itu jumlah aborsi di Indonesia diperkirakan mencapai 2,3 juta pertahun. Sekitar 750.000 diantaranya dilakukan oleh remaja. Sedangkan berdasarkan data Riskesdas tahun 2010 yang dirilis Kementerian Kesehatan RI.

Menurut Adiningsih (2002) dalam Pikiran Rakyat (2010), pengetahuan tentang kesehatan reproduksi pada remaja sangatlah minim, informasi yang kurang akurat dan benar tentang kesehatan reproduksi sehingga memaksa remaja untuk melakukan eksplorasi sendiri, baik melalui media (cetak maupun elektronik) dan hubungan pertemanan, yang besar kemungkinannya justru salah. Ternyata 
sebagian besar remaja merasa tidak cukup nyaman curhat dengan orang tuanya, terutama bertanya seputar masalah seks. Oleh karena itu, remaja lebih suka mencari tahu sendiri melalui sesama temannya dan menonton blue film. Selain itu pengetahuan tentang akibat pernikahan dini dan kesiapan secara fisik merupakan salah satu hal yang harus diperhatikan pada pasangan yang menikah diusia muda terutama pihak wanitanya. Hal ini berkaitan dengan kehamilan dan proses melahirkan. Secara fisik, tubuh mereka belum siap untuk melahirkan anak dan melahirkan karena tulang panggul mereka yang masih kecil sehingga membahayakan persalinan. Hal tersebut sangat mempengaruhi angka kematian ibu dan angka kematian bayi sebagai standart derajat kesehatan suatu negara.

Menikah diusia dini terutama di bawah usia 20 tahun ternyata memiliki risiko yang cukup mengkhawatirkan. Secara mental belum siap menghadapi perubahan yang terjadi saat kehamilan, belum siap menjalankan peran sebagai seorang ibu dan belum siap menghadapi masalah-masalah berumah tangga yang sering kali melanda kalangan keluarga yang baru melangsungkan perkawinan, karena masih dalam proses penyesuaian. Sementara itu remaja yang melangsungkan perkawinan diusia dini umumnya belum memiliki kematangan jiwa dalam arti kemantapan berpikir dan berbuat. Pada umumnya remaja yang melangsungkan perkawinan dibawah umur 20 tahun belum memiliki pandangan dan pengetahuan yang cukup tentang bagaimana seharusnya peran seorang ibu dan seorang istri atau peran seorang laki-laki sebagai bapak dan kepala rumah tangga. Keadaan semacam ini merupakan titik rawan yang dapat mempengaruhi keharmonisan dan kelestarian perkawinan. Menurut Badan Kependudukan dan Keluarga Berencana Nasional (BKKBN), menikah diusia dini bagi perempuan besar kemungkinan melahirkan anak dengan berat badan rendah dan memiliki tubuh pendek atau stunting (kontet). Anak stunting itu tubuhnya pendek, kecil, dan ukuran otak kecil. Risikonya mudah kena penyakit jantung dan pembuluh darah (BKKBN, 2012).

Dari fakta yang didapat, dengan melihat dan menelaah bahwa mereka yang menikah muda akan lebih cenderung untuk mengalami kegagalan dalam rumah tangga mereka. Namun dalam alasan perceraian bukan karena alasan nikah muda, melainkan ekonomi dan lain sebagainya. Tetapi masalah tersebut tentu saja sebagai salah satu dampak dari pernikahan yang dilakukan tanpa kematangan usia dan psikologis. Perkawinan yang masih muda juga banyak mengundang masalah yang tidak diharapkan dikarenakan segi psikologisnya 
belum matang khususnya bagi perempuan (Walgito, 2000).

Basri, (1996) mengatakan secara fisik biologis yang normal seorang pemuda atau pemudi telah mampu mendapatkan keturunan, tetapi dari segi psikologis remaja masih sangat hijau dan kurang mampu mengendalikan batera rumah tangga di samudra kehidupan. Selain itu remaja juga belum siap dan mengerti tentang hubungan seks, sehingga akan menimbulkan trauma psikis berkepanjangan dalam jiwa remaja yang sulit disembuhkan. Remaja akan murung dan menyesali hidupnya yang berakhir pada perkawinan yang dia sendiri tidak mengerti atas putusan hidupnya. Selain itu, ikatan perkawinan akan menghilangkan hak remaja untuk memperoleh pendidikan (Wajar 9 tahun), hak bermain dan menikmati waktu luangnya serta hak-hak lainnya yang melekat dalam diri anak. Berapa banyak keluarga dalam perkawian terpaksa mengalami nasib yang kurang beruntung dan bahkan tidak berlangsung lama karena usia terlalu muda dari para pelakunya, baik salah satu atau keduanya. Usia ideal perempuan untuk menikah adalah 19-25 tahun sementara laki-laki 25-28 tahun karena di usia itu organ reproduksi perempuan secara psikologis sudah berkembang dengan baik dan kuat serta siap untuk melahirkan keturunan secara fisik pun mulai matang. Sementara laki- laki pada usia itu kondisi psikis dan fisiknya sangat kuat, hingga mampu menopang kehidupan keluarga untuk melindungi baik psikis emosional, ekonomi dan sosial.

Pernikahan yang dilakukan pada usia muda bukanlah hal yang bisa dikatakan menguntungkan bahkan jelas dapat merepotkan kaum perempuan. Dalam hal ini mereka dituntut untuk mengurus rumah tangga, melayani suami, mengandung dan melahirkan pada usia muda sangat beresiko tinggi bagi kesehatan. Oleh sebab itu dalam hal ini peneliti menyatakan bahwa manfaat dari penundaan usia perkawinan meliputi empat aspek, yaitu : aspek kesiapan biologis, kesiapan psikologis, kesiapan sosial dan kesiapan ekonomi. Hal ini berarti bahwa semakin positif sikap subjek penelitian terhadap psikoedukasi yang diberikan untuk memiliki intensi pernikahan dini, maka akan semakin kuat intensi penundaan pernikahan dini pada subjek penelitian. Pada penelitian ini, peneliti memiliki beberapa indikator yang akan diungkap dalam penelitian, yaitu: menumbuhkan rasa intensi penundaan dengan cara memberikan psiedukasi terhadap pernikahan dini, mengubah persepsi terhadap cara pandang pernikahan dini, memberikan pemahaman terhadap pentingnya intensi penundaan pernikahan dini untuk menurunkan pernikahan usia dini. 
Berdasarkan uraian tersebut rumusan masalahnya, yaitu bagaimana pengaruh psikoedukasi tentang risiko perkawinan usia muda dalam menurunkan intensi pernikahan dini pada remaja, sehingga risiko dari pernikahan dini dapat diminimalisir Tujuan penelitian yaitu untuk mengetahui adanya pengaruh sebelum dan sesudah pemberian psikoedukasi perkawinan usia muda dalam menurunkan intensi pernikahan dini pada remaja. Manfaat penelitian untuk mendapatkan kontribusi perbaikan dalam intensi pernikahan dini pada remaja.

\section{Intensi Pernikahan Dini}

Intensi merupakan probabilitas atau kemungkinan yang bersifat subjektif, yaitu perkiraan seseorang mengenai seberapa besar kemungkinannya untuk melakukan suatu tindakan tertentu. Artinya, mengukur intensi adalah mengukur kemungkinan seseorang dalam melakukan perilaku tertentu untuk memprediksi perilaku manusia yang menunjukkan kekuatan motivasi seseorang untuk menghasilkan perilaku yang dimaksud (Anwar, Bakar, \& Harmaini, 2005; Eagly \& Chaiken 1993).

Pernikahan dini yaitu merupakan intitusi agung untuk mengikat dua insan lawan jenis yang masih remaja dalam satu ikatan keluarga. Pernikahan dini umumnya dilakukan dibawah usia yang seharusnya belum siap untuk melaksanakan pernikahan (Lutfiati, 2008; Nukman, 2009 ). Jika intensi dikaitkan dengan pernikahan dini maka dapat disimpulkan bahwa intensi pernikahan dini merupakan penundaan suatu perkawinan yang ingin menikah diusia remaja atau dibawah umur 20 tahun, dimana pada masa remaja ini ketegangan emosi meninggi sebagai akibat dari perubahan fisik dan kelenjar.

\section{Aspek Intensi Pernikahan Dini}

Menurut Ajzen \& Fishben (1975) dan Ajzen (2005), intensi mengandung empat elemen yang berbeda yaitu :

a) Tindakan (action) yaitu tindakan apa yang dilakukan oleh seseorang terhadap suatu objek. Chaplin (2005) menambahkan bahwa tindakan adalah hasil perbuatan atau tingkah laku yang bertujuan.

b) Sasaran (target) yaitu apa yang ingin dituju atau sasaran apa yang ingin dicapai, merupakan sasaran yang hendak dicapai dari perilaku spesifik tersebut.

c) Konteks (context) yaitu situasi atau keadaan yang dikehendaki untuk manampilkan perilaku tertentu, meliputi tempat, situasi atau keadaan pada individu itu sendiri.

d) Waktu (time) yaitu meliputi waktu yang diperlukan untuk mewujudkan perilaku tertentu. Intensi untuk berperilaku dapat 
Psikologia (Jurnal Psikologi), 1 (1), June 2016, 1-14

ISSN 2338-8595 (print), ISSN 2541-2299 (online) Journal Homepage: http://ojs.umsida.ac.id/index.php/psikologia

DOI: 10.21070/psikologia.v1i1.749

muncul dengan mempertimbangkan suatu waktu tertentu (jam), suatu periode tertentu (bulan) atau sebuah waktu yang tidak terbatas (masa yang akan datang).

\section{Komponen yang Bisa Memunculkan Intensi}

Teori Perilaku Terencana (Theory of Planned Behavior) yang dikemukakan Ajzen \& Fishben (1975); Ajzen (2005); Azwar (1995) menyebutkan adanya tiga komponen yang bisa memunculkan intensi, yaitu :

a) Sikap terhadap perilaku (attitude toward the behavior) yaitu mengacu pada penilaian individu bahwa perilaku yang akan dilakukan itu baik atau buruk, suka atau tidak suka menjalankan perilaku itu.

b) Norma subjektif (subjective norm) yaitu mengacu pada persepsi individu terhadap tekanan sosial yang mengharuskan atau melarangnya untuk menjalankan perilaku yang bersangkutan.

c) Persepsi atas kendali perilaku (perceived behavioral control) yaitu mengacu pada keyakinan individu bahwa ia mampu atau tidak mampu menjalankan perilaku tertentu. Keyakinan ini dapat berasal dari pengalaman dengan perilaku yang bersangkutan di masa lalu, perolehan informasi tidak langsung mengenai perilaku tersebut dan dapat pula dipengaruhi oleh faktor-faktor lain yang mengurangi atau menambah kesan kesukaran untuk menjalankan perilaku yang bersangkutan.

Dalam hal ini, dua komponen pertama sudah cukup untuk memunculkan intensi, sebagaimana disebut dalam teori reasoned behavior yang diajukan oleh Fishbein (Fishbein \& Ajzen, 1975) sebelum kemudian disempurnakan oleh Ajzen (Ajzen, 2005) lewat teori planned behavior. Faktor ketiga sifatnya memerkuat atau memerlemah intensi. Jika perilaku tersebut dipandang mungkin untuk dilakukan, intensi menguat. Jika perilaku itu dianggap sulit atau tidak mungkin dilakukan, intensi menyurut atau menurun.

\section{Psikoedukasi}

Psikoedukasi adalah suatu intervensi yang dapat dilakukan pada individu, keluarga, dan kelompok yang fokus pada mendidik partisipannya mengenai tantangan signifikan dalam hidup, membantu partisipan mengembangkan sumber-sumber dukungan dan dukungan sosial dalam menghadapi tantangan tersebut bahkan mengembangkan keterampilan coping untuk menghadapi tantangan tersebut.

Berdasarkan pengertian tersebut dapat ditarik kesimpulan bahwa fokus dari psikoedukasi yaitu: (a) Mendidik partisipaan mengenai tantangan dalam hidup. (b) Membantu partisipan mengembangkan sumbersumber dukungan dan dukungan sosial dalam 
menghadapi tantangan hidup (c) Mengembangkan keterampilan coping untuk menghadapi tantangan hidup. (d) Mengembangkan dukungan emosional. (e) Mengurangi sense of stigma dari partisipan. (f) Mengubah sikap dan belief dari partisipan terhadap suatu gangguan (disorder). (g) Mengidentifikasi dan mengeksplorasi perasaan terhadap suatu isu. (h) Mengembangkan keterampilan penyelesaian masalah. (i) Mengembangkan keterampilan crisisintervention (Griffiths, 2006 dikutip Walsh, 2010).

Psikoedukasi adalah suatu bentuk pendidikan ataupun pelatihan terhadap seseorang dengan gangguan psikiatri yang bertujuan untuk proses treatment dan rehabilitasi. Sasaran dari psikoedukasi adalah untuk mengembangkan dan meningkatkan penerimaan pasien terhadap penyakit ataupun gangguan yang ia alami, meningkatkan pertisipasi pasien dalam terapi dan pengembangan coping mechanism ketika pasien menghadapi masalah yang berkaitan dengan penyakit tersebut (Goldman, 1998 dikutip dari Bordbar \& Faridhosseini, 2010). Psikoeduakasi adalah treatment yang diberikan secara profesional dimana mengintegrasikan intervensi psikoterapeutik dan edukasi (Lukens \& McFarlane, 2004).

\section{Hipotesis}

Ada pengaruh pemberian psikoedukasi perkawinan usia muda dalam menurunkan intensi pernikahan dini pada remaja.

\section{METODE PENELITIAN}

\section{Rancangan Penelitian}

Termasuk penelitian eksperimen quasi. Desain eksperimen yang pengendaliannya terhadap variabel-variabel non eksperimental yang tidak begitu ketat dan penentuan sampelnya dengan tidak randomisasi. Metode yang digunakan berupa pre experimental design dengan jenis pre-test and post-test one group design. Metode ini diberikan pada satu kelompok saja tanpa kelompok pembanding.

\section{Subjek Penelitian}

Subjek penelitian ditentukan secara purposive, yaitu siswa-siswi kelas VII, VIII dan IX dari 2 sekolah yang rawan pernikahan dini, berusia antara 13-15 tahun. Adapun setelah dilakukan screening didapatkan subjek penelitian sebanyak 55 subjek dengan kategori intensi pernikahan dini sedang, tinggi, dan sangat tinggi.

\section{Prosedur dan Analisa Data Penelitian}

Tahap pertama yaitu persiapan, hal ini dimulai dari peneliti untuk melakuakan suatu pendalaman materi dan adaptasi alat ukur yang harus sudah bisa diterapkan bagi subjek yang 
akan di psikoedukasi. Namun teknik pengolahan data digunakan untuk menilai keampuhan instrumen penelitian. Langkah-langkah yang ditempuh dalam penyusunan instrumen dilakukan dalam beberapa tahap, baik dalam pembuatan atau uji cobanya. Untuk lebih jelasnya dapat dilihat pada bagan berikut :

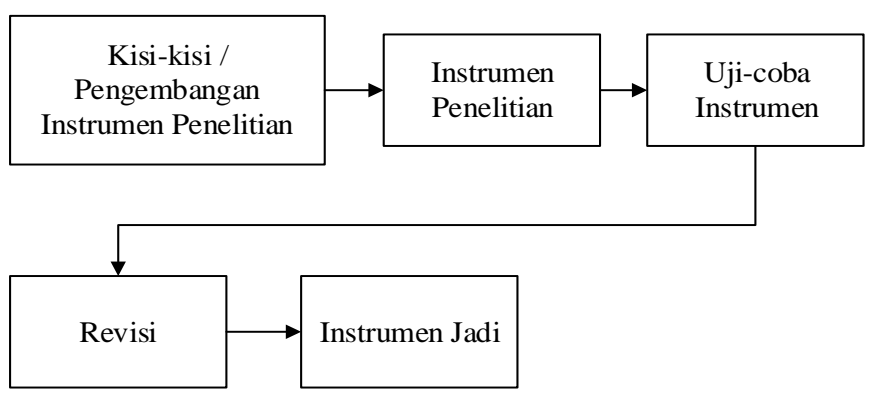

Gambar 1. Prosedur Penyusunan Instrumen

Pada tahap kedua yaitu peneliti menyusun modul psikoedukasi. Setelah modul selesai disusun, selanjutnya dilakukan uji coba modul, agar modul benar-benar reliabel sesuai dengan tujuan penelitian. Langkah-langkah penyusunan modul sebagaimana bagan berikut:

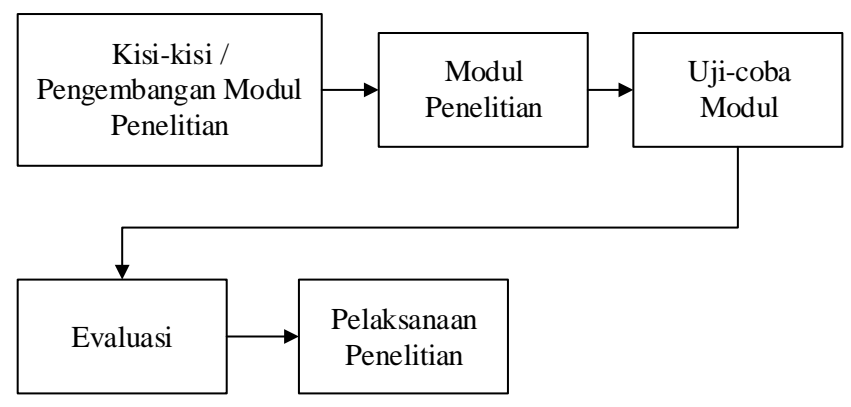

Gambar 2. Prosedur penyusunan modul
Tahap ketiga yaitu penyebaran skala pertama terhadap 2 sekolah yang dianggap rawan terjadinya pernikahan dini dengan berupa pre-test. Pada penyebaran skala ini bertujuan untuk mengkategorikan kelayakan subjek untuk mengikuti psikoedukasi yang akan diberikan oleh peneliti serta didampingi oleh guru BK ataupun Psikolog.

Pada tahap keempat, peneliti mulai memberikan psikoedukasi terhadap penurunan intensi pernikahan dini. Hal ini dilakukan untuk mengubah persepsi para remaja yang sudah memiliki keinginan untuk melakukan pernikahan usia dini, dengan cara memberikan pemahaman kepada mereka terhadap dampak dari pernikahan dini serta hal-hal yang mencangkup dalam pernikahan dini. Pada saat psikoedukasi ini, subjek sudah diseleksi berdasarkan hasil pre-test yang masuk dalam kategori sedang, tinggi dan sangat tinggi. Subjek yang digunakan dalam penelitian ini berjumlah 55 orang. Peneliti memilih subjek sesuai dengan kategori yang sudah ditentukan karena untuk mengetahui adanya pengaruh sebelum diberikan perlakuan berupa psikoedukasi dan sesudah pemberian psikoedukasi. Peran peneliti dalam eksperimen berupa pemberian psikoedukasi ini adalah sebagai narasumber.

Tahap kelima yaitu analisis data secara keseluruhan hasil dari penelitian. Data-data 
yang sudah diperoleh dari hasil pre-test dan post-test diinput, diolah dengan menggunakan program SPSS for window ver. 20, yaitu analisis parametrik Paired Sample t Test. Hasil dari analisis ini mendapatkan suatu perbedaan antara sebelum diberikan perlakuan (pre-test) dan sesudah diberikan perlakuan (post-test).

\section{HASIL PENELITIAN}

Berdasarkan hasil penelitian dapat diuraikan sebagaimana berikut;

Tabel 1. Deskripsi Data Intensi Pernikahan Dini

\begin{tabular}{lccc}
\hline Kategori & $\mathrm{N}$ & \multicolumn{2}{c}{ Rerata Skor } \\
\cline { 3 - 4 } & & Pre-test & Post-test \\
\hline Laki-laki & 22 & 10.97 & 21.77 \\
\hline Perempuan & 33 & 11.48 & 22.69 \\
\hline Jumlah & 55 & & \\
\hline
\end{tabular}

Berdasarkan tersebut diperoleh hasil yang menunjukkan bahwa hasil rata-rata lakilaki yang berjumlah 22 orang dan perempuan yang berjumlah 33 orang memiliki perbedaan. Pada subjek laki-laki dalam rata-rata pre-test mendapatkan hasil 10.97 dan rata-rata post-test mendapatkan hasil 21.77. Sedangkan pada subjek perempuan dalam rata-rata pre-test mendapatkan hasil 11.48 dan rata-rata post-test mendapatkan hasil 22.69. Hal ini dapat disimpulkan bahwa pada saat sebelum diberikan perlakuan subjek perempuan lebih cenderung untuk melakukan intensi pernikahan dini. Pada penelitian ini secara keseluruhan subjek berjumlah 55 orang.

\section{Tabel 2. Deskriptif Uji Paired Sample t Test Data Pre-test dan Post-test}

\begin{tabular}{cllccc}
\hline N & \multicolumn{2}{c}{$\begin{array}{c}\text { Rerata } \\
\text { Skor }\end{array}$} & Correlation & T & P \\
\cline { 2 - 4 } & Pre & Post & & & \\
\hline 55 & 11.25 & 22.33 & 0.265 & -39.305 & 0.000 \\
\hline
\end{tabular}

Berdasarkan tersebut, selanjutnya menganalisis skor intensi pernikahan dini pada remaja sebelum diberikan perlakuan dan sesudah diberikan perlakuan berupa psikoedukasi perkawinan usia muda dengan menggunakan uji Paired Sample t Test untuk melihat perbedaan pre-test dan post-test. Pada bagian ini diperoleh hasil korelasi 0.265 , hal ini menyatakan bahwa korelasi antara sebelum dan sesudah pemberian psikoedukasi berhubungan secara nyata. Sedangkan terlihat pada tabel nilai $\mathrm{t}(-39,305)$ dan hasil uji analisis Paired Sample $t$ Test diperoleh nilai $\mathrm{P}<0,05(\mathrm{p}=0,000)$. Hasil tersebut menunjukkan adanya perbedaan skor yang signifikan terhadap perlakuan tanpa psikoedukasi (pre-test) dan dengan perlakuan psikoedukasi (post-test). Hal ini menunjukkan bahwa adanya perbedaan sebelum diberikan psikoedukasi dan sesudah diberikan perlakuan psikoedukasi. 
DOI: $10.21070 /$ psikologia.v1i1.749

\section{PEMBAHASAN}

Berdasarkan hasil dari penelitian ini, menunjukkan bahwa adanya penurunan intensi pernikahan dini pada remaja melalui psikoedukasi perkawinan usia muda. Hal ini dibuktikan dengan adanya perbedaan sebelum diberikan perlakuan psikoedukasi dimana hasil dari pre-test menunjukkan bahwa subjek yang terpilih, masuk dalam kategori yang sudah di tentukan oleh peneliti dan sesudah diberikannya perlakuan psikoedukasi dimana intensi pernikahan dini pada subjek mengalami penurunan. Tingkat keberhasilan ini berdasarkan uji analisis Paired Sample t Test dengan memiliki perbedaan yang signifikan sebelum dan sesudah diberikannya perlakuan.

Secara umum menurut Riskesdas, (2010) Perempuan muda di Indonesia dengan usia 10-14 tahun menikah sebanyak 0,2 persen atau lebih dari 22.000 wanita muda berusia 1014 tahun di Indonesia sudah menikah. Hal ini di buktikan dengan hasil dari pre-test antara lakilaki dan perempuan mengalami perbedaan. Pada subjek laki-laki dalam rata-rata pre-test mendapatkan hasil 10.97 sedangkan subjek perempuan dalam rata-rata pre-test mendapatkan hasil 11.48. Pada dasarnya perempuan memiliki keinginan yang lebih tinggi dalam melakukan suatu pernikahan dengan kurangnya pengetahuan. Adiningsih,
(2002) dalam Pikiran Rakyat (2010), pengetahuan tentang kesehatan reproduksi pada remaja sangatlah minim, informasi yang kurang akurat dan benar tentang kesehatan reproduksi sehingga memaksa remaja untuk melakukan eksplorasi sendiri, baik melalui media (cetak dan elektronik) dan hubungan pertemanan, yang besar kemungkinannya justru salah. Ternyata sebagian besar remaja merasa tidak cukup nyaman curhat dengan orang tuanya, terutama bertanya seputar masalah seks.

Psikoedukasi secara umum dapat mendidik dan membantu partisipan mengembangkan sumber-sumber dukungan dalam menghadapi tantangan hidup dan pada penelitian kali ini mengacu pada penurunan intensi seseorang dengan setiap aspeknya terkait keinginan individu untuk melakukan pernikahan dini. Psikoedukasi (Griffiths, 2006 dikutip Walsh, 2010) merupakan suatu intervensi yang dapat dilakukan pada individu, keluarga, dan kelompok yang fokus untuk mendidik partisipannya mengenai tantangan signifikan dalam hidup, membantu partisipan mengembangkan sumber-sumber dukungan dan dukungan sosial dalam menghadapi tantangan tersebut dan mengembangkan keterampilan coping untuk menghadapi tantangan tersebut. Hasil yang didapat dengan menggunakan psikoedukasi ini berpengaruh positif dalam 
intensi individu agar tidak memiliki keinginan atau pun akan melakukan suatu pernikahan dini.

Psikoedukasi tidak hanya bertujuan untuk treatment tetapi juga rehabilitasi. Ini berkaitan dengan mengajarkan seseorang mengenai suatu masalah sehingga mereka bisa menurunkan intensi yang terkait dengan pernikahan dini dan mencegah agar masalah tersebut tidak terjadi pada masa yang akan datang. Psikoedukasi juga didasarkan pada kekuatan partisipan dan lebih fokus pada saat ini dan masa depan dari pada kesulitan-kesulitan di masa lalu. Psikoedukasi, baik individu ataupun kelompok tidak hanya memberikan informasiinformasi penting terkait dengan permasalahan partisipannya tetapi juga mengajarkan keterampilan-keterampilan yang dianggap penting bagi partisipannya untuk menghadapi situasi permasalahannya. Psikoedukasi dapat diterapkan pada berbagai kelompok usia dan level pendidikan. Asumpsi lainnya, psikoedukasi kelompok lebih menekankan pada proses belajar dan pendidikan dari pada selfawareness dan self-understanding dimana komponen kognitif memiliki proporsi yang lebih besar dari pada komponen afektif (Brown, 2011). Namun ini tidak berarti bahwa psikoedukasi sama sekali tidak menyentuh aspek selfawareness dan self-understanding. Hal ini dikembalikan kepada sasaran dari psikoedukasi itu sendiri anak-anak, remaja, dan orang dewasa.

Teori-teori yang melatarbelakangi psikoedukasi antara lain adalah teori sistem ekologi, teori kognitif-perilaku, teori belajar, group practice models, stress and coping models, model dukungan sosial, dan pendekatan naratif (Anderson, Reiss, \& Hogarty, 1986, dikutip dari Lukens \& McFarlane, 2004). Pada penelitian ini lebih mengarah pada teori kognitif dimana lebih berfokus pada penguasaan terhadap keterampilan kognisi-emosi yang menjadi komponen dari proses psycho-training. Kognisi yang dalam penelitian ini adalah memberikan pengetahuan kepada subjek terkait dengan pernikahan dini yang dapat berdampak buruk bagi masa remaja mereka dan psikoedukasi yang diberikan mampu menanamkan pola hidup yang lebih baik untuk merancang masa depan mereka dengan menunda suatu pernikahan dini. Setelah selesai dilakukannya perlakuan psikoedukasi, peneliti memberikan kesempatan kepada subjek yang dapat review ulang terkait dengan materi psikoedukasi yang sudah disampaikan peneliti. Subjek yang dapat memberikan review ulang maka peneliti memberikan reward sebagai stimulus. Hal ini bertujuan agar para subjek bersemangat dalam mendengarkan materi psikoedukasi. 
Pada tahap ini, remaja juga sudah mulai mampu berspekulasi tentang sesuatu, dimana mereka sudah mulai membayangkan sesuatu yang diinginkan di masa depan. Perkembangan kognitif yang terjadi pada remaja juga dapat dilihat dari kemampuan seorang remaja untuk berpikir lebih logis. Namun pada masa remaja akan menimbulkan ketakutan-ketakutan terhadap orang tua, karena pada masa remaja masa mencari identitas diri yang kemungkinan besar menimbulkan beberapa pertentangan dengan orang tua.

\section{SIMPULAN}

Hasil penelitian ini membuktikan bahwa psikoedukasi yang diberikan kepada remaja mampu menurunkan intensi untuk menikah dini. Psikoedukasi untuk menurunkan intensi menikah dini dapat diberikan dalam program Bimbingan dan Konseling di tingkat sekolah.

Pada peneliti selanjutnya dapat mengulangi penelitian ini dengan berbagai variasi dan perbaikan. Variasi dapat dilakukan dengan merancang modul pelatihan lebih cermat dan menarik, seperti dalam bentuk komik atau majalah remaja. Peneliti juga sebaiknya dapat menindak lanjuti penyuluhan psikoedukasi perkawinan usia muda yang tidak hanya menurunkan intensi pernikahan dini pada subjek, namun kedalam bentuk perubahan perilaku. Secara lebih luas, replikasi dapat dilakukan pada sampel yang lebih bervariasi dalam hal usia, tempat dan waktu karena dengan pemilihan subjek yang lebih luas dapat menggeneralisasikan hasil penelitian pada populasi yang lebih luas pula.

\section{DAFTAR PUSTAKA}

Ahmad, A. H.. (2012). Pernikahan Usia Dini. Diunduh dari https://hasanzainuddin.wordpress.com /2012/09/17/pernikahan-dini-ancaman besar-kehidupan-sosial-kalsel/.

Adiningsih, N. (2002). Kualitas dan profesionalisme Guru. Pikiran Rakyat 15 Oktober 2002. Http://www.Pikiran Rakyat.com/1-2-2/15 Opini.

Azwar, S. (1995) Sikap Manusia Teori dan pengukuranya. Edisi 2. Yogyakarta: Pustaka Pelajar Offset.

Ajzen, I. (2005). Attitudes, Personality, and Behavior, Edisi kedua. New York: Open University Press.

Ahmad, S.A., Hakim, E.H., \& Makmur, L. (2009). Ilmu Dan Kegunaan TumbuhTumbuhan Obat Indonesia. Bandung : ITB.

Anwar, K., Bakar, A., \& Harmaini. (2005). "Hubungan antara Komitmen Beragama dengan Intensi Prososial Mahasiswa Fakultas Psikologi UIN Suska Riau”, dalam Jurnal Psikologi, Volume 1, Nomor 2, Desember 2005. Pekan Baru: Fakultas Psikologi UIN Sultan Syarif Kasim Riau. 
Psikologia (Jurnal Psikologi), 1 (1), June 2016, 1-14

ISSN 2338-8595 (print), ISSN 2541-2299 (online)

Journal Homepage: http://ojs.umsida.ac.id/index.php/psikologia

DOI: 10.21070/psikologia.v1i1.749

Arikunto, S. (2002). Prosedur Penelitian, Suatu

Pendekatan Praktek. Jakarta: PT Rineka Cipta.

Arikunto, S. (2006). Prosedur Penelitian Suatu Pendekatan Praktik, Edisi Revisi VI, Penerbit PT Rineka Cipta, Jakarta.

Basri, H. (1996). Merawat Cinta Kasih. Yogyakarta : Pustaka Pelajar.

Badan Penelitian dan Pengembangan Kesehatan. (2010). Riset Kesehatan Dasar (Riskesdas 2010), Kementerian Kesehatan Republik Indonesia, Jakarta.

BKKBN. (2012). Pernikahan Usia Dini. Scribd.com. Diunduh dari. Www.acribd.com/doc/171421448/HasilPernikahan-Usia-Dini-BKKBN-PPT-RSRead-Inly\#scribd.

Bordbar, M. \& Faridhosseini, F. (2010). Psychoeducation for Bipolar Mood Disorder. Jurnal: Clinical, Research, Treatment Approaches to Affective Disorders.

Brown, N. W. (2011). Psychoeducational Groups 3rd Edition: Process and Practice. New York: Routledge Taylor \& Francis Group.

Chaplin, J.P. (2004). Kamus Lengkap Psikologi, cet. ke-9, Penerjemah: Dr. Kartini Kartono, Jakarta: Rajawali Pers.

Eagly, A. H. \& Chaiken, S. (1993). The Psychology of Attitudes. Fort Worth, TX: Harcourt Brace Jovanovitch.

Echols, J. M., \& Shadily, H. (2000).Kamus Inggris Indonesia, cet. ke-25, Jakarta: Gramedia.
Esa.un.org. (2010). United Nations Development Economic and Social Affairs, Popilation Division, World Population Prospects: The 2008 Revision.

Gay, L.R. \& Diehl. P.L. (1992). Research Methods for Business and Management. MacMillan Publishing Company. New York.

Griffiths, P. (2006). An Introduction to English Semantics and Pragmatics. Edinburgh University Press Ltd.

Kusmiran, E. (2011).Kesehatan Reproduksi Remaja Dan Wanita.Jakarta: Salemba Medika.

Lukens, E. P. \& McFarlane, W. R. (2004). Journal Brief Treatment and Crisis Intervention Volume 4. Psychoeducation as Evidence-Based Practice: Consideration for Practice, Research, and Policy. Oxford University Press.

Lutfiati. (2008). Pernikahan Dini Pada Kalangan Remaja (15-19 tahun). http://nyna0626.blogspot.com. Diakses 4 April 2010.

Nukman, I. (2009). Mind Revolution!. Jogyakarta: Diva Press.

Maulana, S. (2013). Seminar tentang Remaja dalam rangkaian Peringatan Hari Keluarga XX Tingkat Nasional. Hotel Azahra, Kendari, Sultra. http://www.bkkbn.go.id/ViewBerita.aspx ?BeritaID=831.

Sugiyono. (2002). Metode Penelitian Administrasi. Bandung: CV Alfabeta. 
Walgito, B. (2000). Bimbingan dan Konseling (Studi dan karier): Penerbit Andi. Yogyakarta.

Wiggins, J. A., dkk. (1994). Social Psychology 5th Edition. San Fransisco. McGraw-HillI 